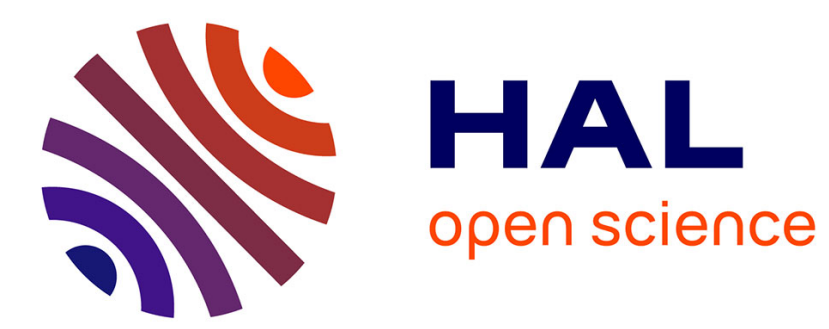

\title{
NEW TECHNIQUE FOR THE DEPOSITION OF HIGH Tc SUPERCONDUCTING FILMS
}

M. Langlet, E. Senet, J. Deschanvres, G. Delabouglise, F. Weiss, J. Joubert

\section{To cite this version:}

M. Langlet, E. Senet, J. Deschanvres, G. Delabouglise, F. Weiss, et al.. NEW TECHNIQUE FOR THE DEPOSITION OF HIGH Tc SUPERCONDUCTING FILMS. Journal de Physique Colloques, 1989, 50 (C5), pp.C5-141-C5-147. 10.1051/jphyscol:1989520 . jpa-00229543

\section{HAL Id: jpa-00229543 https://hal.science/jpa-00229543}

Submitted on 1 Jan 1989

HAL is a multi-disciplinary open access archive for the deposit and dissemination of scientific research documents, whether they are published or not. The documents may come from teaching and research institutions in France or abroad, or from public or private research centers.
L'archive ouverte pluridisciplinaire HAL, est destinée au dépôt et à la diffusion de documents scientifiques de niveau recherche, publiés ou non, émanant des établissements d'enseignement et de recherche français ou étrangers, des laboratoires publics ou privés. 


\title{
NEW TECHNIQUE FOR THE DEPOSITION OF HIGH $T_{\mathrm{C}}$ SUPERCONDUCTING FILMS
}

\author{
M. LANGLET, E. SENET, J.I. DESCHANVRES, G. DELABOUGLISE, F. WEISS and \\ J.C. JOUBERT \\ LMGP/CNRS, ECole Nationale Supérieure de Physique de Grenoble, Domaine \\ Universitaire, $B P .46, F-38402$ st Martin d'Hères, France
}

\begin{abstract}
Resumé: Des couches minces supraconductrices de composition $\mathrm{YBa}_{2} \mathrm{Cu}_{3} \mathrm{O}_{7-\mathrm{x}}$ ont été obtenues par une nouvelle technique de dépot, basée sur la pyrolyse d'un aérosol pulvérisé par voie ultrasonore et contenant les précurseurs $\mathrm{Y}-\mathrm{Ba}-\mathrm{Cu}$. Cette technique conduit à un très bon aspect de surface des films et permet de controler précisément leur épaisseur.Les couches d'à peu près 0.2 à $6 \mu \mathrm{m}$ d'épaisseur ont été recuites à l'air à $500^{\circ} \mathrm{C}$, chauffées sous oxygène à des températures de $900 \mathrm{à} 960^{\circ} \mathrm{C}$, puis refroidies lentement à température ambiante sous oxygène. Cette méthode conduit à des couches bien cristallisées, présentant une bonne homogénéité de taille de grain et une texture dans la direction 001 dépendant des conditions de traitement thermique. Des céramiques et monocristaux de $\mathrm{SrTiO}_{3}, \mathrm{YSZ}$ ou $\mathrm{MgO}$ ont été utilisés comme substrats. Dans cet article on discute l'influence des conditions expérimentales sur la microstructure, la morphologie et les propriétés supraconductrices des films.
\end{abstract}

\begin{abstract}
Thin films of $\mathrm{YBa}_{2} \mathrm{Cu}_{3} \mathrm{O}_{7-\mathrm{x}}$ superconductors have been prepared using a new deposition technique based on the pyrolysis of an ultrasonic generated aerosol containing the $\mathrm{Y}$-Ba-Cu precursors. This technique leads to a very good quality of the film surface and allows to control accurately the film thickness. Films of about 0.2 to $6 \mu \mathrm{m}$ in thickness have been annealed in air at $500^{\circ} \mathrm{C}$, heated under oxygen at temperatures ranging from 900 to $960^{\circ} \mathrm{C}$ and then slowly cooled in oxygen to room temperature. This method leads to well crystallized $\mathrm{YBa}_{2} \mathrm{Cu}_{3} \mathrm{O}_{7-\mathrm{x}}$ films with a good grain size homogeneity and a texture in the 001 direction depending on the heat treatment conditions. $\mathrm{SrTi0}_{3}, \mathrm{YSZ}$ or $\mathrm{Mg0}$ single crystals and ceramics have been used as substrates. In this paper we discuss the influence of the experimental conditions on the microstructure, morphology and superconducting properties of the films.
\end{abstract}

\section{Introduction}

The discovery of superconductivity at $40 \mathrm{~K}$ in Ba-La-Cu-O system / $1 /, 90 \mathrm{~K}$ in $\mathrm{Y}-\mathrm{Ba}-\mathrm{Cu}-0$ system $/ 2 /$ and more recently $110 \mathrm{~K}$ in $\mathrm{Bi}-\mathrm{Sr}-\mathrm{Ca}-\mathrm{Cu}-\mathrm{O}$ system $/ 3 /$ has encouraged an increasing interest in developping high $\mathrm{T}_{\mathrm{C}}$ superconductive thin films both for fundamental purposes and technological devices operating in liquid nitrogen and at higher temperatures. Many results on $\mathrm{YBa}_{2} \mathrm{Cu}_{3} \mathrm{O}_{7-\mathrm{x}}$ thin films deposition involve high vacuum equipments such as d.c. magnetron sputtering /4-5/, R.F reactive sputtering /6/ or laser beam evaporation $/ 7 /$. The high cost of these physical deposition techniques has recently promoted a new interest in developping non vacuum chemical techniques. Simple and inexpensive chemical processes such as spray deposition /8-9/, diping or spinning techniques /10-11/, screen printing procedure $/ 12 /$ and sol gel process $/ 13 /$ have been successfully used in different laboratories for the deposition of superconducting $\mathrm{YBa}_{2} \mathrm{Cu}_{3} \mathrm{O}_{7-\mathrm{x}}$ thin films. However these processes do not allow to control carefully 
the thickness and homogeneity of submicronic films. To our knowledge no positive results concerning the deposition of $\mathrm{YBaCuO}$ thin films by $\mathrm{CVD}$ techniques have been reported in the litterature. The transport of Ba vapors appears very problematic owing to the poor volatility of the existing Ba precursors. Recently we have developped an ultrasonically assisted CVD method /14-16/ which was successfully used for the deposition of magnetic films /17-18/ and transparent semiconductor films $/ 19 /$ with a thickness of 0.1 to $1 \mu \mathrm{m}$ or more. This method led to a very accurate control of the film thickness and homogeneity. The technique has been now modified in order to allow the transport and deposition of non volatile compounds. Experimental procedure involves the pyrolysis on a heated substrate of an ultrasonically generated aerosol containing the precursors. Mineral and organic precursors such as nitrates, acetates or acetylacetonates have been successfully used for the deposition of $\mathrm{YBa}_{2} \mathrm{Cu}_{3} \mathrm{O}_{7-x}$ films. In this paper we discuss the first results obtained with nitrate precursors.

\section{Experimental}

$\mathrm{Y}\left(\mathrm{NO}_{3}\right)_{3} 4 \mathrm{H}_{2} \mathrm{O}, \mathrm{Ba}\left(\mathrm{NO}_{3}\right)_{2}$ and $\mathrm{Cu}\left(\mathrm{NO}_{3}\right)_{2} 3 \mathrm{H}_{2} \mathrm{O}$ were dissolved in the proportion 1: $2: 3$ with a total concentration of about $0.05 \mathrm{M} /$, in a solution $60 \%$ acetic acid, $40 \%$ desionized water. The experimental device is

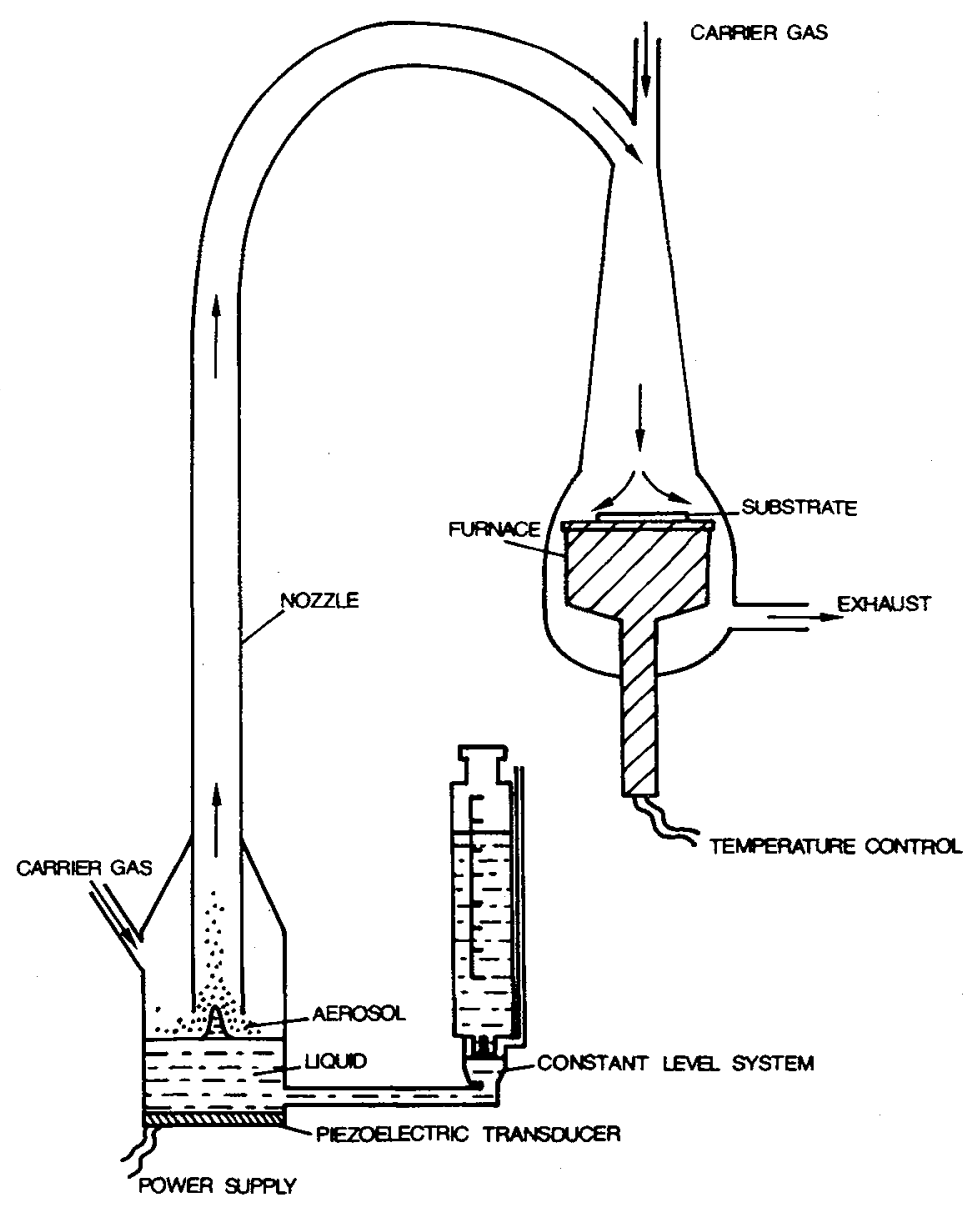

Fig.1 : Deposition system 
shown in figure 1. The solution was stored in a glass vessel whose bottom was fitted with a piezoelectric transducer. Excitation of the piezoelectric transducer at its resonance frequency (about $800 \mathrm{kHz}$ ) led to the formation of a mist of microscopic droplets at the liquid surface. That aerosol was then transported by an air flow of about $10 \mathrm{l} / \mathrm{mn}$ through a spray nozzle towards the heated substrate fixed on a round shapped flat resistance furnace. Substrates were single crystals and ceramics of strontium titanate (STO), yttrium stabilized zircona (YSZ) or magnesium oxide (MgO). These compounds appeared in the litterature /4 to 13/ as the best sustrates for $\mathrm{YBa}_{2} \mathrm{Cu}_{3} \mathrm{O}_{7-\mathrm{x}}$ films deposition. The substrate surface was maintained at a temperature of about $150^{\circ} \mathrm{C}$ controlled with a thermocouple embedded into the surface plate near the heating element. This temperature was choosen in order that the dropplets vaporize as soon as they reach the heated sustrate leading to a dry precipitate which adheres uniformaly to the substrate. A depressurizing device allowed the evacuation of deposition gases.The thickness of films deposited in about 1 hour ranged from 0.2 to $1 \mu \mathrm{m}$. The deposition rate was closely controlled by the quantity of precursor transported by unity of time. As we reported previously /17/ this quantity is the product of the aerosol flow (monitored by the ultrasonic excitation power) by the precursor concentration in the source liquid. It was then possible to monitor accurately the deposition rate by a simple control of the ultrasonic power level.

Homogeneity of the films was directly related to the ultrasonic pulverization method. The average size of the uitrasonically sprayed droplets is closely controlled by the frequency of the piezoelectric generator. This frequency dependance leads to a narrow size distribution and a smaller droplet size in the case of ultrasonic spray than in the case of classical pneumatic spray. An average size of about 3-4 microns is obtained using a water solution. The uniformity and small size of the droplets contributes in turn to the good quality of films as thin as $2000 \AA$, because all the droplets vaporize at the same temperature and lead to the deposition of very fine, dense and uniform grains on the substrate. A carefull control of the substrate temperature was a second important factor contributing to the good quality of the films. At a too low temperature the droplets did not vaporize and led to a wet coating. At a too high temperature they vaporized well before to reach the substrate leading to agglomeration of the dry precipitate and then to a non adherent and non uniform powder coating.

As deposited films of about 0.2 to 1 micron in thickness were pre-annealed in air at $500^{\circ} \mathrm{C}$ for $30 \mathrm{mn}$. The cycle of deposition and preheating was repeated 1 to 6 times in order to control the thickness of the films. Films were then annealed for 5 to $60 \mathrm{mn}$ under oxygen at temperatures ranging from 900 to $960^{\circ} \mathrm{C}$ and then cooled to room temperature in about 10 hours.

\section{Results}

Fig. 1 shows the films $X$ ray patterns at the different steps of the elaboration process. $X$ ray pattern of as deposited films (fig. 2a) showed only baryum nitrate reflexion lines suggesting that this compound has precipitated on the substrate in larger grains than yttrium or copper nitrate. Pre-annealing at $500^{\circ} \mathrm{C}$ led to a significant improvement of the film adherence as shown by the scotch tape test. Pre-annealed films X ray pattern (fig. $2 b$ ) showed baryum carbonate and copper oxide diffraction peaks. Yttrium oxide must be present in the film, in the form of amorphous grains or very small microcrystallites. After heat treatment between 900 and $960^{\circ} \mathrm{c}$ under oxygen the films Xray pattern exhibited mostly the diffraction peaks of the $\mathrm{YBa}_{2} \mathrm{Cu}_{3} \mathrm{O}_{7-x}$ cuprate (fig. 2c). Films thinner than 0.5 micron appeared strongly textured in the 001 direction when heated at $950^{\circ} \mathrm{C}$ for only $5 \mathrm{mn}$. The films texture was observed to decrease when increasing the thickness above one micron. Increasing the duration and/or temperature of the crystallization heat treatment led to a signficant improvement of the thick films texture. 3 microns thick films appeared completely textured in the 001 direction when heated under oxygen for $60 \mathrm{mn}$ at $950^{\circ} \mathrm{C}$. Thin textured films $(\mathrm{t}<1$ micron) were mainly composed of disk shapped grains (fig. 3a) of about one micron in diameter and deposited parallel to the substrate. Thicker textured films were composed of larger grains (fig. $3 b$ ). It is remarkable that the morphology and strong texture of the films did not depend on the nature and crystalline state of the substrate. Strongly oriented films were 

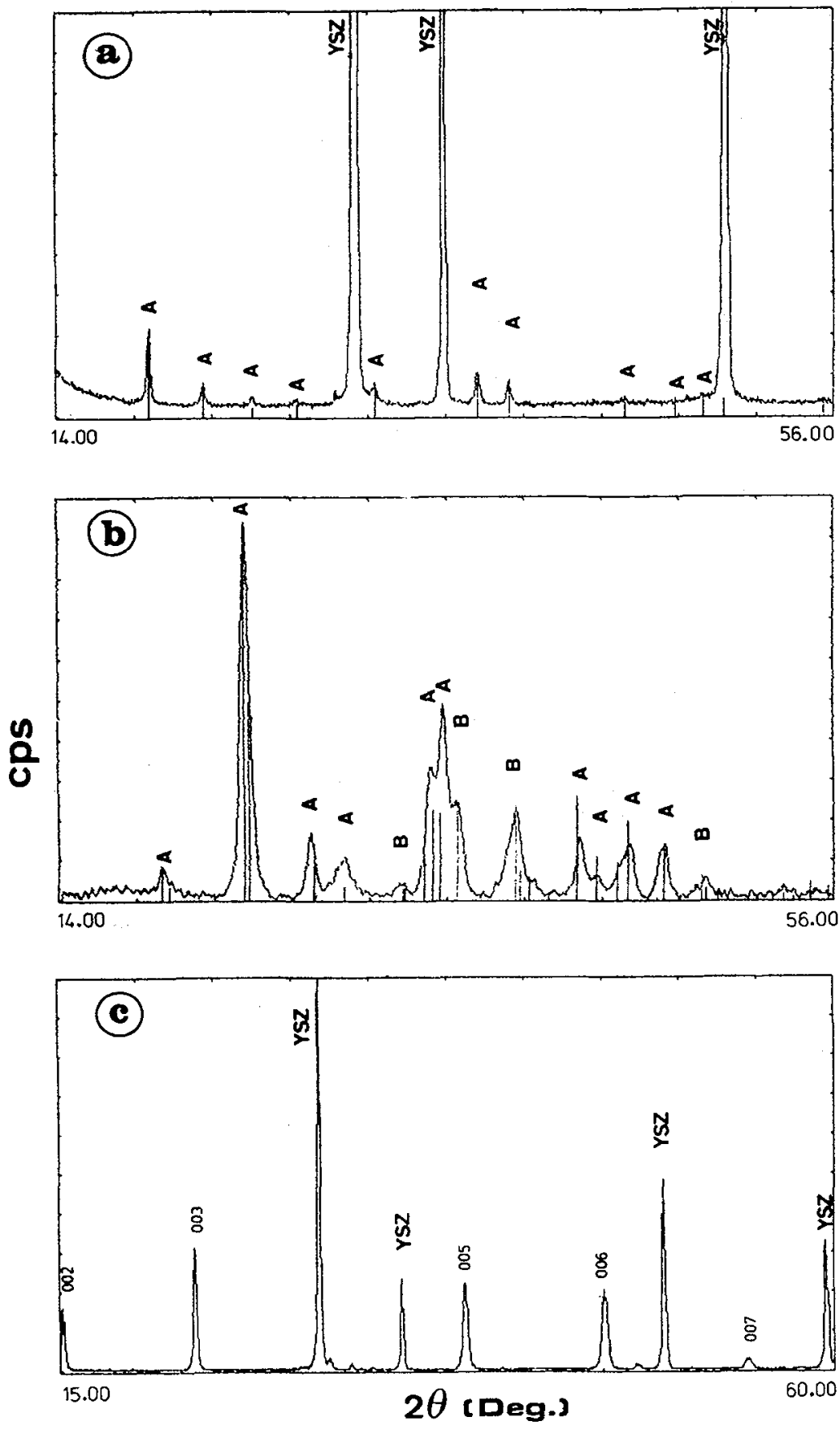

Fig.2 a / X-ray pattern of a non annealed film deposited on a YSZ ceramic $\left(\mathrm{A}=\mathrm{Ba}\left(\mathrm{NO}_{3}\right)_{2}\right)$

$\mathrm{b} / \mathrm{X}$-ray pattern after annealing in air at $500^{\circ} \mathrm{C}$ of a film deposited on a YSZ single-crystal. $\left(\mathrm{A}=\mathrm{BaCO}_{3}, \mathrm{~B}=\right.$ $\mathrm{CuO}$ )

c/ X-ray pattern after annealing in oxygen at $950^{\circ} \mathrm{C}$ of a 001 textured $\mathrm{YBa}_{2} \mathrm{Cu}_{3} \mathrm{O} 7-\mathrm{x}$ film deposited on a YSZ ceramic (the film thickness is $5000 \AA$ ). The copper $\mathrm{K} \alpha$ radiation has been used. 


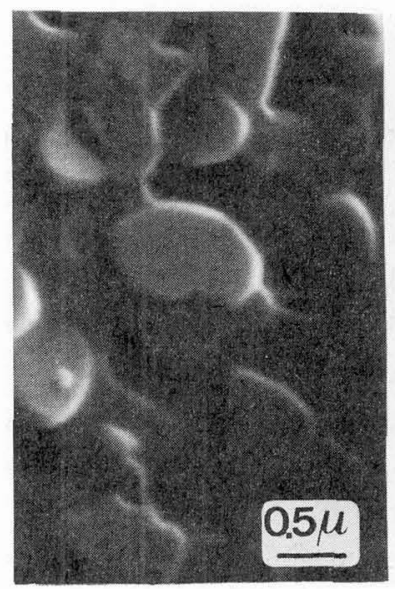

a

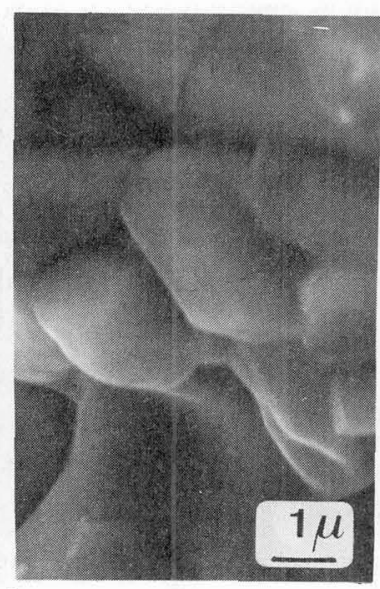

b

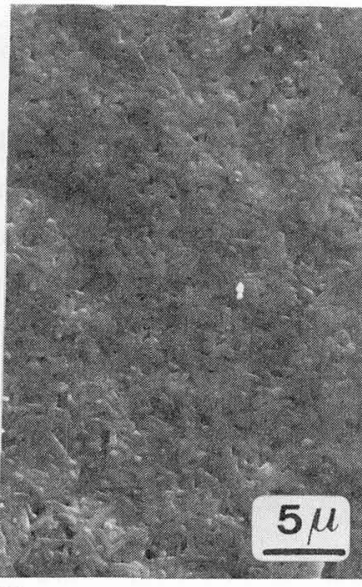

C

Fig.3 a/ Morphology of a 001 textured $\mathrm{YBa}_{2} \mathrm{Cu}_{3} \mathrm{O}_{7-\mathrm{x}}$ film of 0.5 micron in thickness

b/ Morphology of a 001 textured $\mathrm{YBa}_{2} \mathrm{Cu}_{3} \mathrm{O}_{7-\mathrm{x}}$ film of 3 microns in thickness

c/ Morphology of a 001 textured $\mathrm{YBa}_{2} \mathrm{Cu}_{3} \mathrm{O}_{7-\mathrm{x}}$ film of 3 microns in thickness: picture of a large area

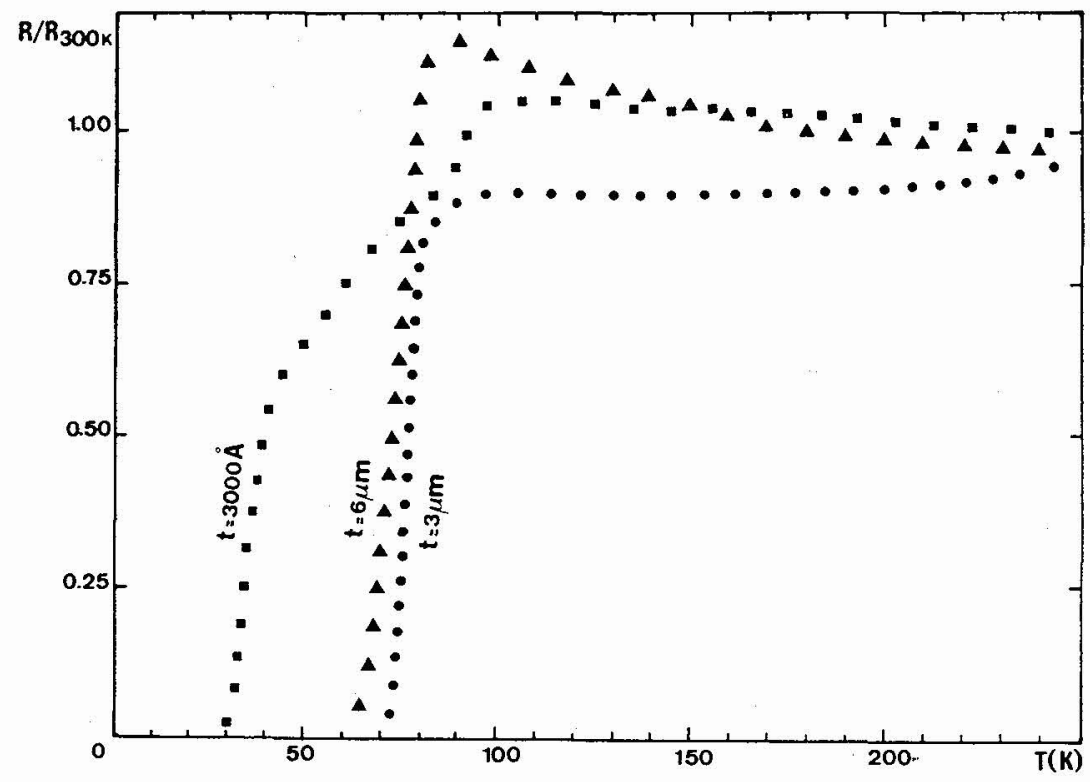

Fig.4 Resistance curve (normalized with respect to the room temperarure resistance value) for $\mathrm{YBa}_{2} \mathrm{Cu}_{3} \mathrm{O}_{7-\mathrm{x}}$ films with different thickness, deposited on $\mathrm{MgO}$ single crystal and annealed in oxygen at $950^{\circ} \mathrm{C}$. 
obtained on single crystal as well as ceramic substrates. SEM pictures of a large area (fig. $3 c$ ) shows that $\mathrm{YBa}_{2} \mathrm{Cu}_{3} \mathrm{O}_{7-\mathrm{x}}$ films were not affected by cracks or voids and exhibited a remarkable grain density and a good smoothness.

As we mentionned previously. $/ 20 \%$, films annealed above $900^{\circ} \mathrm{C}$ were partially affected by an interfatial chemical reaction with the different substrates used for this study. Depending on the substrate nature the $\mathrm{CuO}, \mathrm{Y}_{2} \mathrm{O}_{3}$, $\mathrm{Y}_{2} \mathrm{Cu}_{2} \mathrm{O}_{5}$ or $\mathrm{Y}_{2} \mathrm{BaCuO}_{5}$ phases were detected in the films by $\mathrm{X}$ ray diffraction. Non identified diffraction peaks were detected as well and were attributed to a perovskite phase, with a cubic cell parameter of about $4.20 \AA$. The composition of this perovskite is probably close to $\mathrm{Ba}_{2} \mathrm{YCuO}_{5-\mathrm{x}} / 20 \%$. Appearance of these phases was all the more marked since the films were thin. This confirms that these phases proceeded from the film-substrate interface and propagated through the film thickness during the annealing treatment. The film-substrate reaction produced a dramatic effect on the composition of submicronic films for which the appearance of contamination phases after annealing a few minutes above $900^{\circ} \mathrm{C}$ was accompanied by a progressive disappearance of the $\mathrm{YBa}_{2} \mathrm{Cu}_{3} \mathrm{O}_{7-\mathrm{x}}$.

$X$ ray diffraction peaks and a strong decrease of the 001 texture. These results show that the duration of the crystallization thermal process was a very critical parameter to be control in order to obtain pure crystallized and textured $\mathrm{YBa}_{2} \mathrm{Cu}_{3} \mathrm{O}_{7-\mathrm{x}}$ submicronic films. Further annealing experiments using conventional furnaces and infrared radiation devices are currently under investigation in our laboratory in order to improve the purity and properties of very thin films. The contamination phases were weakly or not detected by $\mathrm{X}$ ray diffraction in the case of films of one micron or more in thickness.

All the $\mathrm{YBa}_{2} \mathrm{Cu}_{3} \mathrm{O}_{7-\mathrm{x}}$ films crystallized under oxygen atmosphere exhibited superconductive behaviours. The room temperature resistivity typically ranged from 1 to $10 \mathrm{~m} \Omega \mathrm{cm}$ and the resistivity did not change significantly when the temperature decreased down to $100 \mathrm{~K}$. Figure 4 shows typical resistance curves (normalized with respect to the room temperature resistance value ) obtained by the four probe method with a current of $1 \mathrm{~mA}$ for films crystallized at $950^{\circ} \mathrm{C}$. In every cases the superconductive onset temperature was observed at about $90 \mathrm{~K}$. In the case of films thinner than one micron the $\mathrm{T}_{\mathrm{c}}$ end was observed at about $30 \mathrm{~K}$. This low value is to be related to the previously described substrate contamination which led to the appearance of poorly superconductive phases in the films. The two step transition observed on fig. 4 for a $3000 \AA$ thick film, shows that the film surface was composed at least of two superconductive phases. For films of about 3 microns in thickness, the temperature dependance of the resistance was basically metallic above the superconductive transition and the transition was sharp. The decrease of resistivity from $90 \%$ to $10 \%$ was observed inside $6 \mathrm{~K}$. In this case the substrate contamined region was thin in comparison with the film thickness and the contamination phases did not affect the superconductive properties of the film surface. Thicker

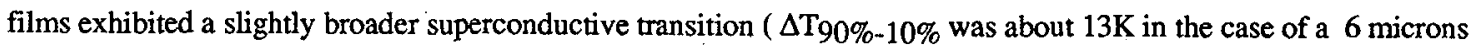
thick film ) and the films exhibited semiconductor behaviours above the $T_{c}$ onset . These data are to be related to the weaker texture observed when the film thickness reached a few microns. Broadly speaking non textured films exhibited poorer superconductive behaviours than textured films.

In summary, we have developped a technique which allows the deposition of $\mathrm{YBa}_{2} \mathrm{Cu}_{3} \mathrm{O}_{7-\mathrm{x}}$ thin films of 0.2 to 6 microns or more in thickness with a precise control of the film thickness and homogeneity. This method allows the deposition of films which are currently not easily achievable by conventional CVD methods. Moreover our technique allows a better control of the films deposition conditions than classical non CVD chemical deposition techniques. These first results demonstrate that it is possible to obtain superconductive films by this technique. We have now to improve the deposition, pre-annealing and crystallization heat treatment conditions in order to minimize the substrate contamination in the case of submicronic films and to optimize the thick films properties. 


\section{References}

/1/ J.G. Bednorz and K.A. Müller, Z. Phys., B 64, 189, 1986.

12/ M.K. Wu, J.R. Ashburn, C.J. Torng, P.H. Hor, R.L. Meng, L. Gao, Z.J. Huang, Y.Q. Wang and C.W. Chu, Phys. Rev. Lett. 58, 908, 1987.

13/ H. Maeda, Y. Tanaka, M. Fukutomi and T. Asano, Jpn. J. App. Phys. 27, L209, 1988.

14/ M. Gurvitch and A.T. Fiory, Appl. Phys. Lett. 51 (13), 1027, 1988.

15/ R.E. Somekh, M.G. Blamire, Z.H. Barber, K. Butler, J.H. James, G. W. Morris, E.J. Tomlinson A.P. Schwarzenberger, W.M. Stobbs and J.E. Evetts, Nature, 326, 857, 1987.

161 J.C. Bruyère, J. Marcus, P.L. Reydet, C. Escribe-Filippini, C. Schlenker, Mat. Research Bull., in press

II X.D. Wu, D. Dijkkamp, S.B. Ogale, A. Inam, E.W. Chase, P.F. Miceli, C.C. Chang, J.M. Tarascon and T. Venkatesan, Appl. Phys. Lett. 51 (11), 861, 1987.

18/ A. Gupta, G. Koren, E.A. Giess, N.R. Moore, E.J.M. O'Sullivan and E.I. Cooper Appl. phys. Lett. 52 (2), 163, 1988.

19/ M. Kawai, T. Kawai, H. Masuhira and M. Takahasi, Jpn. J. of Appl. Phys., 26 (10), L1740, 1987.

/10/ M.E. Gross, M. Hong, S.H. Liou, P.K. Gallagher and J. Kwo, Appl. Phys. Lett. 52 (2), 160, 1988.

/11/ I. Shih and C.X. Qiu, Appl. Phys. Lett. 52 (9), 748, 1988.

112/ R.P. Gupta, W.S. Khokle, R.C. Dubey, S. Singhal, K.C. Nagpal, G.S.T. Raoand J.D. Jain, Appl. Phys. Lett. 52 (23), 1987, 1988.

/13/ P. Barboux, J.M. Tarascon, B.G. Bagley, L.H. Greene, G.W. Hull, B.W. Meagher and C.B. Eom, Mat. Res. Soc. Symp. Proc. Vol. 99, 49, 1988.

/14/ J. Spitz and J.C. Viguie, French Patent 7038371 (1970).

/15/ J.C. Viguie and J. Spitz, J. electrochem. Soc. 122 (4), 585, 1975.

/16/ G. Blandenet, M. Court and Y. Lagarde, Thin Solid Films, 77, 81, 1981.

/17/ M. Langlet, M. Labeau and J.C. Joubert, IEEE Trans. Mag. Vol. MAG $22 \mathrm{n}^{\circ}$ 3, 151, 1986 and Vol. MAG $22 n^{\circ} 5,600,1986$.

/18/ M. Langlet, J.L. Deschanvres, M. Labeau and J.C. Joubert, Int. Symp. on Trends and New Applications in Thin Films, p. 279, Strasbourg, 1987.

/19/ M. Labeau, M. Langlet, V. Reboux, J.C. Joubert, Le Vide Les Couches Minces, 227, 315, 1985.

120/ M. Langlet, E. Senet, J.L. Deschanvres, G. Delabouglise, F. Weiss, J.C. Joubert, E-MRS conference, Strasbourg, 1988. 